\begin{tabular}{|c|c|c|c|c|}
\hline JURNAL & \multirow{2}{*}{ NOMOR 1 } & HALAMAN 1-13 & $\begin{array}{l}\text { ISSN 2655-8823 }(p) \\
\text { ISSN 2656-1786 }(e)\end{array}$ \\
\hline KOLABORASI RESOLUSI KONFLIK
\end{tabular}

\title{
PERILAKU DISKRIMINATIF PADA PEREMPUAN AKIBAT KUATNYA BUDAYA PATRIARKI DI INDONESIA DITINJAU DARI PERSPEKTIF KONFLIK
}

\author{
Sarah Apriliandra \\ Program Studi Ilmu Kesejahteraan Sosial Universitas Padjadjaran \\ E-mail:sarah19009@mail.unpad.ac.id \\ Hetty Krisnani \\ Departemen Kesejahteraan Sosial Universitas Padjadjaran \\ E-mail: hettykrisnani123@gmail.com
}

\begin{abstract}
ABSTRAK
Ketidaksetaraan gender sudah menjadi isu yang lama tidak terpecahkan. Di seluruh penjuru dunia, baik di negara maju maupun berkembang masih mengalami permasalahan ketimpangan gender yang bermuara pada meningkatnya perilaku bersifat diskriminasi kepada kaum yang menjadi termarjinalkan akibat ketimpangan tersebut, yaitu khususnya pada kaum perempuan. Indonesia sendiri merupakan negara yang mendapatkan warisan budaya patriarki dari bangsa penjajah. Budaya ini masih meresap cukup kuat pada sebagian masyarakat Indonesia, di mana mereka mempercayai kendali tunggal laki-laki atas segala hal. Sehingga, tidak jarang kaum perempuan mendapatkan perlakuan yang tidak adil di masyarakat dalam berbagai bentuk. Artikel ini menggunakan metode penelitian kualitatif dan pengumpulan data dengan studi pustaka. Melalui perspektif konflik dari pendekatan multidimensional yang digunakan untuk meninjau isu ini, dapat disimpulkan bahwa budaya patriarki menjadi salah satu faktor besar dari banyaknya perlakuan diskriminatif kepada perempuan sampai saat ini dikarenakan susunan kekuasaan pada berbagai aspek nyatanya didominasi oleh kaum lakilaki.
\end{abstract}

Kata kunci: patriarki, ketidaksetaraan gender, diskriminasi, feminis, konflik.

\section{PENDAHULUAN}

Menjadi seorang perempuan di Tanah Air memiliki tantangan tersendiri. Pasalnya, kaum perempuan di Indonesia masih sering mendapatkan perlakuanperlakuan tidak adil dari masyarakat, khususnya laki-laki. Hal ini karena adanya persepsi atas kekuatan perempuan masih di bawah laki-laki dalam berbagai aspek seperti politik, pendidikan, lingkungan pekerjaan, dan sebagainya. Pandangan ini meresap menjadi sebuah unsur kebudayaan, di mana masyarakat masih mempercayai kendali tunggal oleh laki-laki dalam banyak bidang sehingga menimbulkan ketidaksetaraan akses dan kesempatan bagi perempuan untuk maju dalam bidang-bidang tersebut. Kebudayaan ini adalah yang kita sebut sebagai budaya patriarki. Menurut Spradley (2007; dalam Israpil, 2017), masyarakat yang menganut sistem sosial dengan persepsi patriarki seringkali menganggap laki-laki memiliki peran yang besar dalam mengangkat derajat perempuan. Spradley (2007; dalam Israpil, 2017) menambahkan bahwa nilai patriarki tersebut melihat perempuan sebagai makhluk yang ditakdirkan untuk mendampingi laki-laki sehingga struktur sosial yang lebih harmonis dan seimbang dapat tercipta.

Ketidaksetaraan akses dan kesempatan pada kaum perempuan ini menjadi salah satu isu yang disorot oleh Perserikatan Bangsa-bangsa, sehingga tercantum pada tujuan kelima dalam Sustainable Development Goals (SDGs) yaitu "Gender Equality and Women's Empowerment". United Nations Development Programme memperkenalkan Gender Inequality Index sebagai perhitungan indeks ketimpangan gender di berbagai negara. GII ini dibentuk atas tiga dimensi sebagai indikator 


\begin{tabular}{|c|c|c|c|c|}
\hline JURNAL & \multirow{2}{*}{ VOLUME 3 } & \multirow{2}{*}{ NOMOR 1 } & HALAMAN 1-13 & $\begin{array}{l}\text { ISSN 2655-8823 }(p) \\
\text { ISSN 2656-1786 }(e)\end{array}$ \\
\hline
\end{tabular}

perhitungannya, yaitu pada aspek kesehatan reproduksi yang diukur oleh angka kematian ibu dan kelahiran remaja, pemberdayaan yang diukur dengan pangsa kursi parlemen yang dipegang oleh wanita dan pencapaian di pendidikan menengah dan tinggi menurut jenis kelamin, serta kegiatan ekonomi yang diukur dengan tingkat partisipasi pasar tenaga kerja untuk perempuan dan laki-laki.

Dalam Human Development Report (2018), GII Indonesia berada pada nomor 0.451, menggambarkan untuk setiap 100.000 orang kelahiran, 126,0 perempuan meninggal lantaran permasalahan dalam kehamilan, serta jumlah kelahiran remaja berada di angka 47,4 kelahiran per 1.000 perempuan usia 15-19 tahun. Lalu pada dimensi pemberdayaan, statistik menggambarkan setidaknya $19.8 \%$ kursi parlemen dipegang oleh perempuan, serta wanita dewasa sudah mencapai taraf pendidikan menengah digambarkan dengan angka 44,5\% dibandingkan 53,2\% rekan laki-laki mereka.

Penelitian lain yang menggambarkan ketidaksetaraan gender di Indonesia disebut dalam 2016 Indonesian National Women's Life Experience Survey (2016 SPHPN): Study on Violence Against Women and Girls (2016), bahwa satu dari tiga perempuan Indonesia berusia 15-64 tahun mengaku pernah mengalami kekerasan fisik dan seksual dilakukan oleh atau bukan pasangannya selama hidupnya, dan statistik juga menunjukkan sekitar 9,4\% perempuan mengalaminya dalam 12 bulan terakhir. Organisasi Equal Measures 2030 (2019), menyatakan bahwa pada tahun 2017, perempuan juga masih menghadapi kendala dalam peraturan dan diskriminasi di sektor ekonomi sebesar $51 \%$.

Selain itu, besarnya taraf partisipasi angkatan kerja wanita Indonesia berada jauh di bawah laki-laki yang menempati kurang lebih $80 \%$ angka partisipasi, dan juga lebih rendah daripada rata-rata untuk negara-negara yang tahap perkembangannya sebanding dengan
Indonesia.

Untuk melihat hubungan perilaku manusia dan lingkungannya perlu digunakan pendekatan multidimensional. Pendekatan multidimensional ini mempertimbangkan banyak aspek yang menjadi faktor pengaruh lingkungan sosial terhadap perilaku manusia. Salah satu sudut pandang yang dapat digunakan dalam pendekatan multidimensional adalah perspektif konflik. Sudut pandang ini menegaskan pada konflik yang timbul akibat ketidaksetaraan dalam distribusi sumber daya (Hutchison, 2015).

Teori konflik yang paling terkenal yaitu oleh Karl Marx (1887/1967; dalam Hutchison, 2015) mulai naik ke permukaan akibat ketidakseimbangan dalam struktur ekonomi saat itu yaitu sistem ekonomi kapitalis. Namun seiring berjalannya waktu, konflik teori yang dikembangkan oleh ahli teori kritis mulai merambat ke permasalahan sosial, budaya, dan politik yang terbawa oleh sistem ekonomi kapitalis tersebut (Hutchison, 2015). Pluralistic theory of social conflict yang dipaparkan oleh Coser (1956; dalam Hutchison) menekankan bahwa konflik sosial yang terjadi sepanjang waktu ini berjumlah lebih dari satu diakibatkan adanya tumpang tindih peran dan status individu dalam kelompok. Konflik sosial yang terjadi diantaranya melibatkan kelompok ekonomi, kelompok rasial, kelompok etnis, kelompok agama dan keyakinan, kelompok umur, kelompok gender dan lain sebagainya. Berdasarkan Collins (2012; dalam Hutchison, 2015), teori yang menggunakan pendekatan pluralistik ini termasuk feminist theory dan critical race theory. Kedua teori tersebut disebut sebagai intersectionality theory yang memperhatikan aspek penindasan dan privilege.

Melihat dari sejumlah data dan kenyataan yang ada di lapangan, tidak bisa dipungkiri bahwa ketidaksetaraan gender khususnya pada kaum perempuan masih terjadi sampai hari ini. Ketimpangan ini terjadi karena berbagai macam faktor dari 


\begin{tabular}{|c|c|c|c|c|}
\hline JURNAL & \multirow{2}{*}{ VOLUME 3} & \multirow{2}{*}{ NOMOR 1 } & HALAMAN 1-13 & $\begin{array}{l}\text { ISSN 2655-8823 }(p) \\
\text { ISSN 2656-1786 }(e)\end{array}$ \\
KOLABORASI RESOLUSI KONFLIK
\end{tabular}

berbagai aspek. Budaya patriarki yang sudah marak sejak dahulu ini menghasilkan perilaku dari individu maupun kelompok yang bersifat diskriminatif kepada kaum perempuan yang menjadi termarjinalkan. Pada artikel ini, penulis akan berfokus kepada perilaku seseorang berdasarkan lingkungan budayanya, yaitu spesifik pada perilaku diskriminatif yang terbentuk karena budaya patriarki dengan perspektif konflik sebagai pendekatan multidimensional yang digunakan. Artikel ini akan menjawab pertanyaan bagaimana budaya patriarki mempengaruhi perilaku diskriminatif kepada kaum perempuan, serta bertujuan untuk menjelaskan kepada publik tentang permasalahan yang menjadi penghambat dalam terealisasinya feminisme di Indonesia dengan mengidentifikasi faktor-faktor yang mempengaruhi manusia berperilaku diskriminatif kepada kaum perempuan.

\section{METODE PENELITIAN}

Penelitian dilakukan menggunakan metode kajian kepustakaan dengan merujuk kepada penelitian-penelitian terdahulu dan sejumlah artikel dari beberapa jurnal. Referensi yang digunakan dalam penulisan artikel dibatasi dalam fokus budaya patriarki, ketidaksetaraan gender, dan perilaku diskriminatif. Artikel memakai sumber referensi utama yaitu "Dimensions of Human Behavior, Person and Environment" oleh Elizabeth D. Hutchison sebagai acuan untuk meninjau fenomena perilaku diskriminatif dengan menggunakan teori perspektif konflik yang melihat penindasan di masyarakat sebagai fenomena yang hadir karena ketidaksetaraan. Penulis menjabarkan aplikasi teori ini sebagai sudut pandang yang digunakan dalam meneliti perilaku manusia dalam lingkungan budaya patriarki. Penulis juga menggunakan beberapa referensi pendukung lainnya.

\section{BUDAYA PATRIARKI DAN KETIDAKSETARAAN GENDER DI INDONESIA \\ Budaya Patriarki}

Budaya patriarki, seperti yang pernah dipaparkan oleh Bressler (2007; dalam Susanto, 2015, merupakan sebuah sistem sosial yang ada di masyarakat, di mana laki-laki menjadi seseorang yang memiliki kewenangan utama sehingga menjadi pusat kontrol dalam sistem sosial tersebut. Bressler (2007; dalam Susanto, 2015) menambahkan, bahwa patriarki sendiri memandang distribusi kekuasaan yang mengungguli kaum laki-laki seperti halnya pada garis keturunan patrilineal, hak-hak anak sulung, kedaulatan pribadi dalam hubungan sosial, keikutsertaan peran dalam publik, contohnya dalam bidang politik, agama, serta okupasi.

Mies (1986; dalam Omara, 2004) mengatakan bahwa budaya patriarki melihat kaum laki-laki ditempatkan pada sistem nilai yang berada di atas perempuan dan mempengaruhi aspek-aspek lain dalam masyarakat, sehingga dapat dikatakan bahwa pada budaya patriarki ini, susunan sosial dalam masyarakat seringkali didominasi oleh laki-laki daripada perempuan. Masalah-masalah yang dihadapi oleh kaum perempuan yang diantaranya merupakan ketimpangan akses dalam berbagai hal di masyarakat, merupakan buah permasalahan yang hadir karena adanya persepsi patriarki tersebut yang masih menjadi kepercayaan bagi sebagian besar masyarakat, khususnya di Indonesia sendiri.

Menurut Muhadjir (2005; dalam Susanto; 2015), isu marginalisasi pada kaum perempuan terletak pada budaya patriarki yang menempatkan laki-laki lebih superior daripada perempuan yang berada dalam posisi subordinat. Penempatan posisi wewenang kaum perempuan inferior pada kaum laki-laki dalam pandangan yang telah meresap menjadi sebuah budaya ini utamanya terlihat pada sistem pembagian sumber daya. Muhadjir (2005; dalam Susanto, 2015) menambahkan, bahwa 


\begin{tabular}{|c|c|c|c|c|}
\hline JURNAL & \multirow{2}{*}{ VOLUME 3 } & \multirow{2}{*}{ NOMOR 1 } & HALAMAN 1-13 & $\begin{array}{l}\text { ISSN 2655-8823 }(p) \\
\text { ISSN 2656-1786 }(e)\end{array}$ \\
\hline
\end{tabular}

kebudayaan ini menjadi salah satu sebab banyaknya perlakuan diskriminatif, pembatasan, eksploitasi dan juga perilaku kekerasan pada kaum perempuan yang terjadi saat ini.

Langgengnya kepercayaan patriarki ini mengakibatkan sebagian kaum perempuan menerima kodratnya sesuai dengan pandangan kewenangan perempuan di bawah laki-laki dan melihat persepsi patriarkis tersebut seperti sesuatu yang sudah seharusnya (Rokhimah, 2014). Perempuan sering dipandang sebagai second-class citizen dan juga sebagai objek dari berbagai upaya perubahan yang ada di masyarakat, tampak pada pemikiran yang mengacu pada asumsi yang berpihak pada laki-laki (Hastuti, 2005).

Di Indonesia sendiri, banyak daerah yang masih mempercayai persepsi patriarki lebih dari sekedar mengikuti garis keturunan patrilineal. Kebudayaan tersebut menjadi unsur kehidupan yang tercermin pada aktivitas sehari-hari, baik dalam lingkup keluarga maupun di masyarakat yang lebih luas. Dapat dilihat pada masyarakat Bali yang menganut garis keturunan patrilineal, mereka memiliki pembagian tugas dan wewenang dalam pernikahan. Masyarakat Bali menganut konsep purusa atau laki-laki berperan kepala keluarga dalam keluarga dan memiliki status kemampuan menanggung tanggung jawab keluarga, sedangkan kaum perempuan yang tidak memiliki kuasa tersebut akan lebih rentan ditempatkan pada posisi di bawah laki-laki (Ariyanti \& Ardhana, 2020).

Bentuk budaya patriarki di lingkungan masyarakat Jawa tergambar pada banyaknya istilah-istilah yang memiliki makna bahwa kaum perempuan inferior pada kaum laki-laki. Dalam Hermawati (2007), disebutkan beberapa istilah Jawa yang mencerminkan budaya patriarki tersebut, diantaranya; kanca wingking yaitu perempuan sebagai teman belakang atau teman untuk mengurus segala urusan rumah tangga dalam hal memasak, mencuci, menjaga anak dan sebagainya
(Hermawati, 2007). Selain itu, ada juga sebutan-sebutan seperti seorang perempuan harus bisa manak, macak, masak yang bermakna bahwa istri sepatutnya mampu memberikan keturunan untuk laki-laki, selalu berpenampilan indah dan berdandan serta memasak untuk suami (Hermawati, 2007).

Salah satu penelitian melihat perempuan Samin di Bojonegoro masih hidup dalam belenggu patriarki karena hanya memiliki peran sebagai pengelola rumah tangga dan tidak adanya penolakan atas aturan patriarkis tersebut walaupun sudah dihadapkan dengan banyak pengaruh dari luar (Huda, 2020). Raharjo (1995; dalam Hermawati, 2007) mengatakan bahwa budaya yang ada di Indonesia menghasilkan imaji perempuan ideal adalah perempuan yang lembut, penurut, dan perannya sebagai perempuan tidak melebihi laki-laki, seperti menjadi seorang istri pengurus rumah tangga yang penurut, dan mendukung karir suaminya. Sistem pandang inilah yang terbentuk secara umum dan menjadi wajar sehingga pemikiran kodrat perempuan berada di bawah laki-laki seakan menjadi cara pandang yang given (Nurcahyo, 2016).

\section{Ketidaksetaraan Gender}

Gender merupakan istilah yang digunakan ilmuwan-ilmuwan sosial untuk menjelaskan perbedaan yang terdapat pada perempuan dan laki-laki sebagai anugerah Tuhan yang juga merupakan budaya yang telah terinternalisasi sejak kecil (Puspitawati, 2012). Perbedaan ini juga merupakan sesuatu yang biologis, seperti dari alat dan fungsi reproduksi perempuan dan laki-laki. Walaupun demikian, perbedaan biologis ini kemudian bertransformasi menjadi sebuah indikator perempuan dan laki-laki berperilaku akibat pengaruh budaya patriarki (Puspitawati, 2012). Ujung tombaknya terlihat pada pembatasan hak, akses, partisipasi dan kontrol yang membentuk tuntutan peran, tugas, kedudukan dan kewajiban pada perempuan (Puspitawati, 2012). Oleh 


\begin{tabular}{|c|c|c|c|c|}
\hline JURNAL & \multirow{2}{*}{ VOLUME 3} & \multirow{2}{*}{ NOMOR 1 } & HALAMAN 1-13 & $\begin{array}{l}\text { ISSN 2655-8823 }(p) \\
\text { ISSN 2656-1786 }(e)\end{array}$ \\
KOLABORASI RESOLUSI KONFLIK
\end{tabular}

karena itu, muncul berbagai bentuk ketidaksetaraan karena adanya persepsi akan peran gender yang mutlak. Ketimpangan utamanya menimpa kaum perempuan, diantaranya pada pandangan yang melihat perempuan dilahirkan melakukan pekerjaan yang terbatas dan memiliki status yang lebih rendah (Wibowo, 2011).

Di Indonesia, budaya yang melihat kaum laki-laki berwenang di atas perempuan ini masih awet hingga kini. Segelintir masyarakat masih menganut persepsi seksis tersebut sehingga timbul berbagai macam bentuk pembatasan dan diskriminasi pada kaum perempuan di berbagai bidang maupun aktivitas. Adanya pengkotak-kotakan sektor yang disebut domestik dan publik membuat ruang gerak perempuan menjadi terbatas ketika ingin berada di taraf yang setara dengan laki-laki di ruang publik.

Masalah ketidaksetaraan gender yang dialami perempuan menurut Bemmelen (2003; dalam Fitrianti \& Habibullah, 2012), meliputi keterbatasan akses dalam pendidikan, nilai yang dianut masyarakat, nilai dan peran gender yang diketahui masyarakat secara umum dari buku pelajaran, dan nilai yang diinternalisasi oleh guru serta kebijakan yang bias gender. Akibat ketidaksetaraan ini, timbul gerakangerakan feminis yang menyuarakan kesetaraan gender sebagai dukungan untuk perempuan untuk mendapatkan hakhaknya. Menurut USAID, "Gender Equality permits women and men equal enjoyment of human rights, socially valued goods, opportunities, resources and the benefits from development results", yang berarti kesetaraan gender memberikan kesempatan yang sama bagi perempuan dan laki-laki dalam menikmati; hakhaknya sebagai manusia, barang bernilai sosial, kesempatan, sumber daya dan manfaat hasil pembangunan (Puspitawati, 2012). Implementasinya di Indonesia terdapat pada Pasal 27 ayat (1) UndangUndang Dasar 1945 yang menjabarkan pengakuan adanya prinsip persamaan untuk seluruh warga tanpa terkecuali, sehingga meliputi penghapusan diskriminasi pada setiap warga negara (Kania, 2015).

Terdapat kajian mengenai kesetaraan gender oleh ahli yang dibagi menjadi empat bagian; Pertama, dalam memenuhi kesetaraan gender, aspek pembagian kerja perempuan dan laki-laki yang berhubungan dengan perbedaan masalah serta kebutuhan pendapatan keluarga sangat diperhatikan; kedua, pada aspek peluang laki-laki dan perempuan dalam menguasai sumber daya, di mana para ahli melihat sudut pandang laki-laki dan perempuan yang meliputi masalah kebutuhan mereka dalam menguasai sumber daya tersebut; ketiga, poin partisipasi laki-laki dan perempuan sangat diperhitungkan untuk merealisasi kesetaraan gender; terakhir, aspek pola pengambilan keputusan dalam keluarga yang dilihat dari beban kerja serta peran laki-laki dan perempuan dalam keluarga (Rahminawati, 2001).

\section{BENTUK-BENTUK DISKRIMINASI PADA PEREMPUAN}

Ihromi (2007; dalam Unsriani, 2014) mengatakan diskriminasi merupakan bentuk sikap dan perilaku yang melanggar hak asasi manusia. Sikap dan perilaku yang termasuk tindakan diskriminatif ini meliputi pelecehan, pembatasan, atau pengucilan terhadap individu dengan faktor ras, agama, ataupun gender sebagai dasarnya (Unsriani, 2014). Perlakuan diskriminatif pada perempuan merupakan manifestasi dari ketidaksetaraan gender dan budaya patriarkis yang masih merajalela.

Pemerintah menerbitkan UndangUndang Nomor 7 Tahun 1984 Pengesahan Konvensi mengenai Penghapusan Segala Bentuk Diskriminasi terhadap Wanita atau yang biasa disebut dengan CEDAW. Berdasarkan $C E D A W$ terdapat beberapa komponen yang tergolong dalam perlakuan diskriminatif; komponen pertama meliputi pandangan dan asumsi tentang peran dan kemampuan perempuan berbasis gender, 


\begin{tabular}{|c|c|c|c|c|}
\hline JURNAL & \multirow{2}{*}{ VOLUME 3 } & \multirow{2}{*}{ NOMOR 1 } & HALAMAN 1-13 & $\begin{array}{l}\text { ISSN 2655-8823 }(p) \\
\text { ISSN 2656-1786 }(e)\end{array}$ \\
\hline
\end{tabular}

yaitu ketika terdapat pemikiran dan prasangka negatif terhadap perempuan sehingga mempengaruhi akses perempuan memperoleh hak dan kesempatannya, maka hal tersebut sudah tergolong diskriminasi; elemen kedua dapat dilihat dari aspek tindakan, yaitu meliputi pembedaan perlakuan, pembatasan serta pengucilan, di mana sebuah tindakan dapat termasuk diskriminasi ketika mengurangi bahkan menghapus hak serta kebebasan yang dimiliki perempuan; komponen selanjutnya meliput niat baik diskriminasi secara langsung ataupun tidak langsung; dan elemen terakhir ditinjau ketika perilaku tersebut menghasilkan dampak seperti pengurangan atau penghapusan pengakuan serta hak dan kebebasan perempuan (Afifah, 2017).

Budaya patriarki berpengaruh pada masalah ketimpangan gender yang dialami perempuan. Akibatnya, perempuan rentan mengalami perilaku yang bersifat diskriminatif di masyarakat. Zulhayatin (2013; dalam Yusalia, 2014) memaparkan wujud dari diskriminasi pada perempuan menjadi lima bentuk yaitu stereotip, subordinasi, marginalisasi, beban berlebihan dan kekerasan.

\section{Stereotip}

Diskriminasi bentuk labeling umum terjadi pada masyarakat yang menganut budaya patriarki. Labeling yang terjadi biasanya bersifat negatif seperti perempuan adalah makhluk yang lemah, sensitif, sering menangis dan sebagainya (Yusalia, 2014). Bentuk-bentuk stereotip yang ada di masyarakat sekarang merupakan buah dari budaya patriarki yang terdahulu. A.P Murniati dalam Budi Santoso, dkk (2000; dalam Budiati, 2010) memberi contoh pada budaya Jawa yang erat dengan patriarki, yaitu ajaran Serat Candrarini, di mana perempuan diajarkan untuk setia, rela dimadu, mencintai sesama, terampil mengerjakan tugas-tugas perempuan, terampil berdandan serta merawat diri, sederhana, melayani kehendak lelaki, perhatian kepada mertua dan rajin membaca buku bertema nasihat. Menurutnya (2000; dalam Budiati, 2010, ajaran-ajaran budaya seperti ini menimbulkan labeling masyarakat terhadap perempuan serta tuntutan sikap dan tingkah laku, lalu ditafsirkan sebagai garis hidup perempuan yang seakan-akan sulit untuk dihilangkan. Dampak dari stereotip adalah perempuan dianggap tidak bisa menempati sektor tertentu, di mana hal tersebut merupakan bentuk perilaku diskriminatif pada perempuan.

\section{Subordinasi}

Perilaku diskriminatif ini berbentuk tindakan pengelompokkan antara dua jenis kelamin dengan menyematkan status sosial tertentu pada salah satunya (Yusalia, 2014). Pada perempuan, subordinasi ini dapat dikatakan sebagai 'penomorduaan' perempuan, yang meletakkan perempuan pada posisi lebih rendah dibandingkan lelaki (Syafe'i, 2015). Oleh Sugihastuti dan Sastriyani (2007; dalam Nasri 2017), perempuan dibatasi pada aktivitas tertentu dan penempatan sosial hasil dari anggapananggapan yang tumbuh di masyarakat seperti anggapan "perempuan adalah makhluk yang emosional dan irasional" sehingga tidak pantas untuk memimpin dan prasangka-prasangka lainnya yang membuat nilai diri perempuan dianggap rendah. Pembentukan anggapan ini umumnya diajarkan terus menerus setiap generasi melalui keluarga, adat, masyarakat, dan lembaga-lembaga lainnya tanpa sengaja ataupun tidak (Syafe'i, 2015). Pemetaan antara dua jenis kelamin ini membuat perempuan menjadi terbelenggu dalam stereotip yang membatasi hak-hak dan kesempatan mereka.

\section{Marginalisasi}

Marginalisasi ialah proses di mana kaum perempuan dipinggirkan sehingga ada pembatasan yang menyulitkan perempuan untuk bertindak, berekspresi dan mengaktualisasi dirinya (Permana \& Maulana, 2020). Djunaedi (2008; dalam 


\begin{tabular}{|c|c|c|c|c|}
\hline JURNAL & \multirow{2}{*}{ VOLUME 3 } & \multirow{2}{*}{ NOMOR 1 } & HALAMAN 1-13 & $\begin{array}{l}\text { ISSN 2655-8823 }(p) \\
\text { ISSN 2656-1786 }(e)\end{array}$ \\
\hline
\end{tabular}

Zahara, Liestyasari \& Nurhadi, 2015) mengatakan bahwa proses ini menempatkan seseorang berdasarkan jenis kelaminnya pada kedudukan yang tidak penting, contohnya perempuan dalam bidang ekonomi, walaupun sebenarnya perempuan memiliki peran yang signifikan pada bidang tersebut. Sosiolog Inggris, Alison Scott dalam Saptari \& Holzner (1997; dalam Khotimah, 2009) membagi marginalisasi menjadi empat bentuk; proses pengucilan perempuan (dari pekerjaan atau jenis kerja lainnya), proses pergeseran perempuan dari pasar kerja (dalam bentuk pemberian pekerjaan yang tidak stabil, upah rendah, dinilai tidak atau kurang terampil dalam suatu sektor), proses feminisasi yaitu perempuan menjadi sentral pada sektor pekerjaan tertentu atau separasi pekerjaan berdasarkan jenis kelamin, dan yang terakhir merupakan proses kesenjangan ekonomi akibat perbedaan upah yang drastis. Marginalisasi ini tidak hanya terlihat dalam sektor pekerjaan, namun juga pada bidang lainnya. Dari sisi kebijakan pemerintah, dapat terlihat bahwa perempuan ditempatkan sebagai second-class citizen (Yusalia, 2014).

\section{Beban Berlebihan}

Beban yang berlebihan ini pada dasarnya cenderung mengarah kepada peran ganda perempuan pada sektor publik dan domestik. Di era digital, perempuan sudah mulai merambah ke ranah publik akibat faktor pendidikan yang meningkat, keinginan untuk berkembang serta mendapatkan penghasilan, namun meningkatnya keinginan perempuan untuk bersaing di sektor publik ini tidak sejalan dengan budaya tertentu yang membuat perempuan masih terhambat (Hidayati, 2016). Budaya masyarakat masih membuat perempuan melakukan peran gandanya sebagai pekerja dalam sektor publik dan sebagai ibu rumah tangga dalam sektor yang disebut domestik. Ramadhani (2016) mengatakan bahwa peran ganda ini dapat terlihat pada seorang perempuan atau istri yang bekerja di luar rumah sehingga mereka harus berupaya untuk menyeimbangkan baik kehidupan rumah tangganya maupun menghasilkan uang. Hal ini tentunya memberatkan perempuan semata dengan dua tugas sementara lelaki hanya ditugaskan untuk mencari nafkah. Padahal, pekerjaan rumah tangga seperti memasak, mencuci dan sebagainya pada dasarnya dapat dilakukan siapa saja, lakilaki sekali pun, dan juga merupakan tanggung jawab seluruh anggota keluarga.

\section{Kekerasan}

Tindakan kekerasan pada perempuan merupakan tindakan diskriminatif yang sering terjadi di masyarakat baik secara mental maupun fisik. Kania (2015) memaparkan beberapa asumsi penyebab adanya kekerasan berbasis gender; pandangan pelaku terhadap korban; hukum yang bias gender, yaitu menurut Subhan (2004; dalam Kania, 2015) hukum tidak berpihak kepada perempuan yang menjadi korban seperti kurang atau tidak adanya perhatian terhadap perempuan dari hukum yang ada; ketentuan relasi gender yang menetapkan suami sebagai kepala rumah tangga menurut UU No 1 Tahun 1974 tentang Perkawinan (Pasal 31 ayat (3)) sehingga menetapkan perempuan dalam posisi yang lebih rendah dalam keluarga.

\section{PEMBAHASAN}

Teori konflik oleh Karl Marx (1887/1967; dalam Hutchison, 2015) mulai naik ke permukaan akibat ketidakseimbangan dalam struktur ekonomi pada sistem ekonomi kapitalis. Seiring berjalannya waktu, teori konflik berkembang pada ranah sosial dan budaya. Perspektif konflik pada dasarnya melihat ketidaksetaraan sebagai hasil dari pembagian sumber daya yang kurang atau tidak merata. Poin utama yang ditekankan pada perspektif teori adalah hubungan antara ketidaksetaraan tersebut dengan pengaturan kekuasaan, serta sistem penindasan. 


\begin{tabular}{|c|c|c|c|c|}
\hline JURNAL & \multirow{2}{*}{ VOLUME 3} & \multirow{2}{*}{ NOMOR 1 } & HALAMAN 1-13 & $\begin{array}{l}\text { ISSN 2655-8823 }(p) \\
\text { ISSN 2656-1786 }(e)\end{array}$ \\
\hline
\end{tabular}

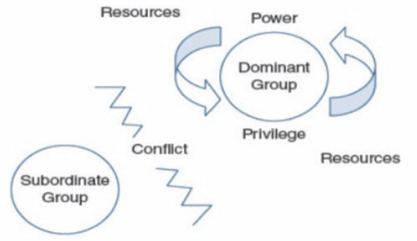

Grafik1.1 Perspektif Konflik.

Grafik ini menunjukkan pola yang menyebabkan konflik antara dua

kelompok (Hutchison, 2015)

Dapat dilihat pada Grafik 1.1 yang tercantum pada buku "Dimensions of Human Behavior, Person and Environment" oleh Elizabeth D. Hutchison, konflik berada di antara kelompok dominan yang mendapatkan akses sumber daya (resources) lebih banyak dan kelompok tersubordinasi yang tidak memiliki akses sumber daya. Ketika distribusi sumber daya lebih berat kepada suatu kelompok mayoritas, maka kelompok tersebut memiliki kekuasaan (power) dan keuntungan (privilege) yang berpusat terus menerus pada mereka. Akibatnya, terjadi konflik antara dua kelompok yang timbul karena ketidaksetaraan ini. Implikasi dari teori konflik akibat ketidaksetaraan ialah bentuk dominasi dan perlakuan tidak adil pada kelompok yang tersubordinasi, seperti diskriminasi dan pemanfaatan privileges yang dimiliki kelompok dominan.

Perspektif konflik yang melihat relasi gender sebagai fokus utamanya adalah teori feminis. Teori ini termasuk dalam sudut pandang konflik karena melihat dari sisi ketidaksetaraan gender yang muncul sebagai bentuk konflik yang terjadi di masyarakat. Teori feminis menekankan hubungan kekuatan dan sumber daya yang terjadi akibat dominasi laki-laki di berbagai macam bidang. Teori ini juga memperhatikan aspek penindasan pada perempuan oleh kaum lain. Dominasi lakilaki yang ada di masyarakat dapat dikaitkan dengan budaya patriarki yang menyebabkan perempuan menjadi salah satu korban ketidaksetaraan gender sehingga rentan mendapatkan perilaku diskriminatif. Bentuk-bentuk diskriminasi yang terjadi pada perempuan merupakan manifestasi dari tidak meratanya sumber daya sosial yang dimiliki perempuan. Terutama pada budaya patriarki, sumber daya sosial ini mayoritas didominasi lakilaki, seperti dukungan untuk menjadi pemimpin, partisipasi dalam bidang politik, menjadi pengambil keputusan utama bagi keluarga, pencari nafkah dengan kemudahan untuk mendapat jabatan tinggi dan sebagainya.

Teori feminis memiliki prinsip intersectionality theory yang juga memperhatikan konsep privilege disamping aspek penindasan pada perempuan. Privilege terbentuk di kalangan kaum dominan yang memiliki akses sumber daya, sehingga menghasilkan kekuasaan. Pada budaya patriarki, laki-laki merupakan kelompok yang memiliki privilege dan kekuasaan tersebut. Contohnya dapat kita lihat dalam berbagai bidang. Pada sektor pekerjaan, tidak jarang laki-laki memiliki keuntungan untuk mendapat pendapatan yang lebih besar daripada perempuan walaupun berada di tingkatan yang sama. Contoh lain, dapat dilihat pada kekuasaan laki-laki pada partisipasi politik sebagai pemimpin. Pada dasarnya, keuntungan dan kekuasaan tersebut mendasari perilaku diskriminatif kaum laki-laki dan kaum dominan lainnya lakukan terhadap perempuan.

\section{KESIMPULAN DAN SARAN \\ Kesimpulan}

Budaya patriarki merupakan budaya yang langgeng, khususnya di Indonesia. Budaya yang mempercayai laki-laki sebagai pemegang kuasa dominan pada berbagai bidang di masyarakat ini menghasilkan anggapan-anggapan tertentu mengenai perempuan yang berpengaruh pada pembatasan hak dan kebebasan perempuan. Pembatasan-pembatasan ini melahirkan isu ketidaksetaraan gender yang menimbulkan wujud-wujud diskriminasi pada perempuan. 


\begin{tabular}{|c|c|c|c|c|}
\hline JURNAL & \multirow{2}{*}{ VOLUME 3} & \multirow{2}{*}{ NOMOR 1 } & HALAMAN 1-13 & $\begin{array}{l}\text { ISSN 2655-8823 }(p) \\
\text { ISSN 2656-1786 }(e)\end{array}$ \\
\hline
\end{tabular}

Perspektif konflik melihat hubungan antara distribusi sumber daya yang timpang dan kekuatan yang dihasilkan akibat hal tersebut. Teori feminis yang lahir sebagai bagian dari sudut pandang konflik menekankan pada dominasi peran laki-laki di masyarakat serta privilege dan kekuasaan yang terbentuk pada kelompok dominan tersebut hasil dari pembagian sumber daya yang timpang. Adanya privilege dan kekuasaan yang dimiliki kaum dominan laki-laki pada budaya patriarki ini membuat mereka dengan mudah menindas perempuan dan melakukan diskriminasi. Privilege yang dimiliki laki-laki ini terlihat dalam berbagai sektor publik, seperti kedudukan status sosial. Keuntungan ini membuat seolah-olah laki-laki memiliki kekuasaan yang mendominasi berbagai sektor publik. Sehingga, gerak perempuan di masyarakat masih terbatas dan memiliki kesulitan dalam pemenuhan hak-hak yang pantas diperoleh perempuan.

\section{Saran}

Pekerja sosial sepatutnya memahami konsep dari ketidakadilan distribusi sumber daya yang merupakan penyebab dari masalah ketidaksetaraan yang ada. Sebagai pekerja sosial, sudut pandang konflik dapat digunakan untuk memahami dinamika privilege dan penindasan atau diskriminasi yang terbentuk akibat ketidaksetaraan. Perspektif konflik melihat aspek historis, budaya, ekonomi, serta politik terhadap kelompok minoritas sehingga terhindar dari pathologizing (memperlakukan individu sebagai seseorang yang tidak sehat secara mental) perilaku individu (Hutchison, 2015), sejalan dengan prinsip pekerja sosial nonjudgemental. Meninjau isu ini menggunakan perspektif konflik membantu pekerja sosial memahami bagaimana dominasi mempengaruhi perilaku manusia (Hutchison, 2015). Pekerja sosial memiliki peran yang dapat dilakukan dalam menyikapi ketidaksetaraan gender dan diskriminasi yang terjadi di masyarakat akibat budaya patriarki dengan beberapa cara.

Teori feminis sebagai sub teori dari sudut pandang konflik dapat diaplikasikan dalam pekerjaan sosial untuk menghadapi permasalahan diskriminasi perempuan. Menurut Suharto (2006) implikasi teori feminis terhadap pekerjaan sosial meliputi terapi individu, terapi kelompok, terapi komunitas, terapi organisasi, analisis kebijakan sosial, dan penelitian pekerjaan sosial. Dalam terapi individu, Suharto (2006) menyebutkan pekerja sosial dapat menerapkan teori feminis untuk memberdayakan perempuan secara ekonomi maupun psikis. Contohnya, pekerja sosial dapat melakukan konseling pada perempuan yang memiliki masalah ekonomi dengan membantu klien mendapatkan sumber daya yang dibutuhkan (Sue, 2006). Salah satu praktik yang disebutkan dalam Hutchison (2015) adalah praktik berorientasi empowerment theories atau teori pemberdayaan. Teori pemberdayaan ini dikembangkan dengan melihat sudut pandang konflik yang menekankan pada proses individu dan kelompok memahami pola ketidaksetaraan dan belajar untuk meningkatkan keberdayaan diri mereka sendiri melalui hal tersebut.

Pekerja sosial juga dapat berperan sebagai perantara yang dalam memberikan pelayanan yang dibutuhkan oleh klien (Sakina, 2017). Adapun peran lain yang dapat pekerja sosial lakukan, yaitu menjadi konselor dengan memberikan bimbingan dan dukungan psikologis melalui activelistening (Sakina, 2017). Suharto (2006) pada terapi kelompok menyebutkan bahwa pekerja sosial dapat melakukan pelatihan yang meningkatkan assertiveness individu. Sands (1998; dalam Sue, 2006) mengatakan bahwa berlatih untuk asertif membantu perempuan meningkatkan kepercayaan diri mereka. Kepercayaan diri tinggi membantu perempuan ketika menghadapi bentukbentuk diskriminasi. Sakina (2017) menambahkan, bahwa pekerja sosial dapat berperan menjadi koordinator. Koordinator 


\begin{tabular}{|c|c|c|c|c|}
\hline JURNAL & \multirow{2}{*}{ VOLUME 3} & \multirow{2}{*}{ NOMOR 1 } & HALAMAN 1-13 & $\begin{array}{l}\text { ISSN 2655-8823 }(p) \\
\text { ISSN 2656-1786 }(e)\end{array}$ \\
\hline
\end{tabular}

ini bisa dalam bentuk membangun tim yang bertujuan untuk membantu individu/korban diskriminasi.

Implementasi terapi komunitas yang disebutkan oleh Suharto (2006), merupakan lembaga-lembaga yang didirikan oleh tokoh-tokoh feminis untuk meningkatkan kesetaraan gender dalam berbagai bidang. Contohnya National Organization of Women yang berdiri pada tahun 1966 sekarang mulai mengusahakan kesetaraan gender pada kebijakan publik. Pekerja sosial sebagai enabler dapat membantu klien mengidentifikasi permasalahan yang muncul (Sakina, 2017), misalnya setelah menghadapi tindakan diskriminasi. Selanjutnya pada aspek terapi organisasi, Suharto (2006) menekankan pada pelatihan administrasi yang harus dikuasai perempuan agar mampu bersaing dalam menempati kedudukan di lembaga pelayanan sosial. Analisis kebijakan sosial yang dilakukan juga dapat menerapkan teori feminis, khususnya pada perjuangan hak-hak kesetaraan dan kebebasan perempuan (Suharto, 2006). Pekerja sosial dapat berperan sebagai negosiator yang menyuarakan hak dan melakukan diskusi dengan pihak-pihak terkait (Sakina, 2017).

Implementasi teori feminis terakhir oleh Suharto (2006) adalah sebagai penelitian pekerjaan sosial, terutama partisipasi perempuan dalam pengembangan riset yang mengkaji istilah feminis. Adapun peran lain pekerja sosial yaitu sebagai advokator, di mana pekerja sosial dapat menolong klien dalam bentuk pendampingan hukum (Sakina, 2017). Pendampingan hukum yang dilakukan dapat meliputi kasus kekerasan terhadap perempuan ataupun bentuk penindasan lainnya. Dalam sektor pendidikan, pekerja sosial juga dapat menjadi advokator yang mendorong perubahan pada sistem (Sue, 2006). Menurut Taylor dan Kennedy (2003; dalam Sue, 2006), pekerja sosial dapat berperan untuk meningkatkan kesadaran pada guru dan staff administrasi pada bidang pendidikan.
Saran lain oleh penulis untuk individu adalah untuk menginternalisasi teori feminis pada diri sendiri maupun pada generasi selanjutnya sejak dini. Teori feminis ini hadir untuk meruntuhkan sistem yang membentuk kelompok dominan dan kelompok tersubordinasi, yang menyebabkan kelompok subordinat ini menerima ketetapan nilai dari kelompok dominan (Kholil, 2016). Tujuan menginternalisasi pemikiran ini adalah agar kedepannya perilaku diskriminatif pada perempuan dapat dihindari dan isu ketidaksetaraan gender di Indonesia maupun dunia semakin berkurang, serta menghapus paham-paham yang menaruh prasangka negatif pada perempuan seperti yang ada pada budaya patriarki.

\section{DAFTAR PUSTAKA}

Afifah, W. (n.d.). Hukum Dan Konstitusi: Perlindungan Hukum Atas Diskriminasi Pada Hak Asasi Perempuan Di Dalam Konstitusi. DiH Jurnal Ilmu Hukum, 13(26), 201. Retrieved December 5, 2020, from http://jurnal.untag-

sby.ac.id/index.php/dih/article/view/15 $\underline{83 / 1342}$

Ariyanti, N. M. P., \& Ardhana, I. K. (2020). Dampak Psikologis Kekerasan dalam Rumah Tangga terhadap Perempuan pada Budaya Patriarki di Bali. Jurnal Kajian Bali (Journal of Bali Studies), 10(1). Retrieved October 21, 2020, from https://ocs.unud.ac.id/index.php/kajian bali/article/view/56832/34278

Budiati, A. C. (2010). Aktualisasi Diri Perempuan dalam Sistem Budaya Jawa (Persepsi Perempuan terhadap Nilainilai Budaya Jawa dalam Mengaktualisasikan Diri). Jurnal Pamator, 3(1), 51. Retrieved December 6, 2020, from https://journal.trunojoyo.ac.id/pamator /article/view/2401/1990

Equal Measures 2030. (n.d.). Gender Equality Context in Indonesia. 


\begin{tabular}{|c|c|c|c|c|}
\hline JURNAL & \multirow{2}{*}{ VOLUME 3} & \multirow{2}{*}{ NOMOR 1 } & HALAMAN 1-13 & $\begin{array}{l}\text { ISSN 2655-8823 }(p) \\
\text { ISSN 2656-1786 }(e)\end{array}$ \\
KOLABORASI RESOLUSI KONFLIK
\end{tabular}

Retrieved December 3, 2020, from https://data.em2030.org/countries/indo nesia/

Fitrianti, R., \& Habibullah. (2012). Ketidaksetaraan Gender Dalam Pendidikan; Studi Pada Perempuan Di Kecamatan Majalaya Kabupaten Karawang. Sosiokonsepsia, 17(1), 85. Retrieved December 5, 2020, from https://ejournal.kemsos.go.id/index.ph $\mathrm{p} /$ SosioKonsepsia/article/view/809/40 

Hastuti, E. L. (2005). Hambatan Sosial Budaya Dalam Pengarusutamaan Gender Di Indonesia (Socio-Cultural Constraints on Gender Mainstreaming in Indonesia). SOCA: Jurnal Sosial Ekonomi Pertanian, 5(2). Retrieved October 21, 2020, from https://ojs.unud.ac.id/index.php/soca/a rticle/view/4084

Hermawati, T. (2007). Budaya Jawa dan Kesetaraan Gender. Jurnal Komunikasi Massa, 1(1). Retrieved October 21, 2020, from https://www.google.com/url?q=https:// digilib.uns.ac.id/dokumen/download/1 0734/MjQxNDM\%3D/Budaya-Jawadan-Kesetaraan-Genderabstrak.pdf\&sa $=$ D\&ust $=16070988793$ 67000\&usg=AOvVaw1_HdgGjMI4T Ubgn7yd1DK

Hidayati, N. (2016). Beban Ganda Perempuan Bekerja (Antara Domestik dan Publik). Muwazah: Jurnal Kajian Gender, 7(2). Retrieved December 6, 2020, from http://ejournal.iainpekalongan.ac.id/index.php /Muwazah/article/view/516

Huda, K. (2020). Peran Perempuan Samin Dalam Budaya Patriarki Di Masyarakat Lokal Bojonegoro. Sejarah dan Budaya: Jurnal Sejarah, Budaya, dan Pengajarannya, 14(1), 76. Retrieved December 6, 2020, from http://journal2.um.ac.id/index.php/seja rah-danbudaya/article/view/12335/5947

Hutchison, E. D. (2015). Dimensions of Human Behavior, Person and
Environment (5th ed.). SAGE Publications, Inc.

Israpil. (2017, Oktober 18). Budaya Patriarki dan Kekerasan Terhadap Perempuan (Sejarah dan Perkembangannya). Pusaka, 5(2), 141. Retrieved October 21, 2020, from https://blamakassar.ejournal.id/pusaka/article/view/176/144

Kania, D. (2015). Hak Asasi Perempuan dalam Peraturan Perundang-undangan di Indonesia: The Rights Of Women In Indonesian Laws And Regulations. Jurnal Konstitusi, 12(4), 716. Retrieved December 5, 2020, from http://digilib.uinsgd.ac.id/4118/

Kholil, M. (n.d.). Feminisme Dan Tinjauan Kritis Terhadap Konsep Gender Dalam Study Islam. Jurnal al- Ulum: Jurnal Pemikiran dan Penelitian ke-Islaman, 3(1), 116-128. https://doi.org/10.31102/alulum.3.1.20 16.116-128

Khotimah, K. (2009). Diskriminasi Gender Terhadap Perempuan Dalam Sektor Pekerjaan. Yinyang: Jurnal Studi Islam Gender Dan Anak, 4(1), 158-180. Retrieved December 6, 2020, from http://www.ejournal.iainpurwokerto.ac .id/index.php/yinyang/article/view/226

Nasri, D. (2017). Ketidakadilan Gender Terhadap Perempuan Dalam Novel Padusi Karya Ka'bati. Madah Jurnal Bahasa dan Sastra, 7(2), 225. 10.26499/madah.v7i2.431

Nurcahyo, A. (2016). Relevansi Budaya Patriaki Dengan Partisipasi Politik Dan Keterwakilan Perempuan Di Parlemen. JURNAL AGASTYA, 6(1), 25. Retrieved December 4, 2020, from http://ejournal.unipma.ac.id/index.php/JA/arti cle/view/878/791

Omara, A. (2004). Perempuan, Budaya Patriarki Dan Representasi. Mimbar Hukum 2004, 2(46), 148. Retrieved October 21, 2020, from http://ilib.ugm.ac.id/jurnal/detail.php?dataId= $\underline{2625}$

Permana, T., \& Maulana, I. (2020). 


\begin{tabular}{|c|c|c|c|c|}
\hline JURNAL & \multirow{2}{*}{ VOLUME 3} & \multirow{2}{*}{ NOMOR 1 } & HALAMAN 1-13 & $\begin{array}{l}\text { ISSN 2655-8823 }(p) \\
\text { ISSN 2656-1786 }(e)\end{array}$ \\
\hline
\end{tabular}

Marginalisasi Perempuan Dalam Cerpen "Inem" Karya Pramoedya Ananta Toer (Sebuah Kajian Feminisme). Jurnal Salaka, 2(1), 5161. Retrieved December 6, 2020, from https://journal.unpak.ac.id/index.php/s alaka/article/view/1837/1496

Puspitawati, H. (2012). Konsep, Teori, dan Analisis Gender. Bogor: Departemen Ilmu Keluarga dan Kon-sumen Fakultas Ekologi Manusia Institut Pertanian. Retrieved December 4, 2020, from http://www.academia.edu/download/5 2842671/gender.pdf

Puspitawati, H. (2012). Gender dan Keluarga: Konsep dan Realita di Indonesia. PT Penerbit ITB Press

Rahminawati, N. (2001). Isu Kesetaraan Laki-laki Dan Perempuan (Bias Gender). Mimbar, 17(3), 272. Retrieved December 6, 2020, from https://ejournal.unisba.ac.id/index.php/ mimbar/article/view/48/pdf

Ramadhani, N. (2016). Implikasi Peran Ganda Perempuan Dalam Kehidupan Keluarga Dan Lingkungan Masyarakat. Sosietas: Jurnal Pendidikan Sosiologi, 6(2). Retrieved December 6, 2020, from

https://ejournal.upi.edu/index.php/sosi etas/article/view/4245/3063

Rokhimah, S. (2014). Patriarkhisme Dan Ketidakadilan Gender. Muwazah, 6(1), 132. Retrieved October 21, 2020, from http://e-

journal.iainpekalongan.ac.id/index.php /Muwazah/article/view/440/392

Sakina, A. I., \& Siti A., D. H. (2017). Menyoroti Budaya Patriarki Di Indonesia. SHARE: Social Work Jurnal, 7(1), 71. Retrieved December 6, 2020, from http://jurnal.unpad.ac.id/share/article/v iew/13820/6628

Sue, D. W. (2006). Multicultural Social Work Practice. John Wiley \& Sons, Inc. Suharto, E. (2006). Teori Feminis dan Social Work. Workshop on Feminist Theory and Social Work, Pusat Studi
Wanita, Universitas Islam Negeri (UIN), Sunan Kalijaga. Retrieved December 6, 2020, from http://www.policy.hu/suharto/Naskah \%20PDF/YogyaFEMINISMESocialW ork.pdf

Susanto, N. H. (2015). Tantangan Mewujudkan Kesetaraan Gender Dalam Budaya Patriarki. Muwazah, 7(2), 120. Retrieved October 20, 2020, from http://ejournal.iainpekalongan.ac.id/index.php /Muwazah/article/view/517

Syafe'i, I. (2015). Subordinasi Perempuan Dan Implikasinya Terhadap Rumah Tangga. Analisis: Jurnal Studi Keislaman, 15(1). https://doi.org/10.24042/ajsk.v15i1.71 $\underline{6}$

United Nations Development Programme. (2019). Human Development Report 2019: Inequalities in Human Development in the 21st Century Briefing note for countries on the 2019 Human Development Report. Retrieved October 5, 2020, from http://hdr.undp.org/sites/all/themes/hdr theme/country-notes/IDN.pdf

United Nations Population Fund. (n.d.). 2016 Indonesian National Women's Life Experience Survey (2016 SPHPN): Study on Violence Against Women and Girls. Retrieved October 8, 2020, from https://indonesia.unfpa.org/sites/defaul $\mathrm{t} /$ files/pubpdf/2016 SPHPN \%28VAW Survey $\% 29$ Key_Findings 1 0.pdf

Unsriana, L. (2014). Diskriminasi Gender dalam Novel Ginko Karya Junichi Watanabe. Lingua Cultura, 8(1). https://doi.org/10.21512/lc.v8i1.441

Wibowo, D. E. (2011). Peran Ganda Perempuandan Kesetaraan Gender. Muwazah, 3(1), 356. Retrieved December 5, 2020, from http://ejournal.iainpekalongan.ac.id/index.php /Muwazah/article/view/6/6

Yusalia, H. (2014). Pengarusutamaan Gender (Pug) Dalam Tantangan Budaya Patriarki. Wardah, 15(2), 195- 


\begin{tabular}{|c|c|c|c|c|}
\hline JURNAL & \multirow{2}{*}{ NOLUME 3} & \multirow{2}{*}{ NOMOR 1 } & HALAMAN 1-13 & $\begin{array}{l}\text { ISSN 2655-8823 }(p) \\
\text { ISSN 2656-1786 }(e)\end{array}$ \\
\hline
\end{tabular}

201.

https://doi.org/10.19109/wardah.v15i2. $\underline{198}$

Zahara, V., Liestyasari, S. I., \& Nurhadi. (2015). Implementasi Pendidikan Adil Gender Di Pondok Pesantren Al- muayyad Surakarta. SOSIALITAS

(Jurnal Ilmiah Pend. Sos-Ant). Retrieved December 6, 2020, from jurnal.fkip.uns.ac.id 